REFLECTIONS:

NEUROLOGY AND

THE HUMANITIES

Section Editor

Anne W. McCammon,

MD, FAAN

Geraint Fuller, MD, FRCP

Correspondence to

Dr. Fuller:

Geraint.Fuller@glos.nhs.uk

\title{
I Come Armed With Words
}

Starting with the history, your story,

I help you find the words to capture

Unfamiliar feelings of disorder or disease.

A translation of sensation to explanation.

Words of kindness, thought and hope

Can give the desperate some rope

To hold above the bleak abyss

When future becomes but prognosis.

Warm words can wash away

The wailing of a weeping woman

When bitter pills and sharp scalpels

Treat the heart though not the spirit.

As but a mortal and physician

The tests and drugs I know are flawed.

And therefore to complete my mission,

I come armed with words. 


\section{Neurology}

\section{Come Armed With Words}

Geraint Fuller

Neurology 2013;80;e179

DOI 10.1212/WNL.0b013e31828f1927

\section{This information is current as of April 22, 2013}

\section{Updated Information \&} Services

\section{Subspecialty Collections}

Permissions \& Licensing

\section{Reprints}

including high resolution figures, can be found at: http://n.neurology.org/content/80/17/e179.full

This article, along with others on similar topics, appears in the following collection(s):

All Clinical Neurology

http://n.neurology.org/cgi/collection/all_clinical_neurology

Information about reproducing this article in parts (figures,tables) or in its entirety can be found online at:

http://www.neurology.org/about/about_the_journal\#permissions

Information about ordering reprints can be found online:

http://n.neurology.org/subscribers/advertise

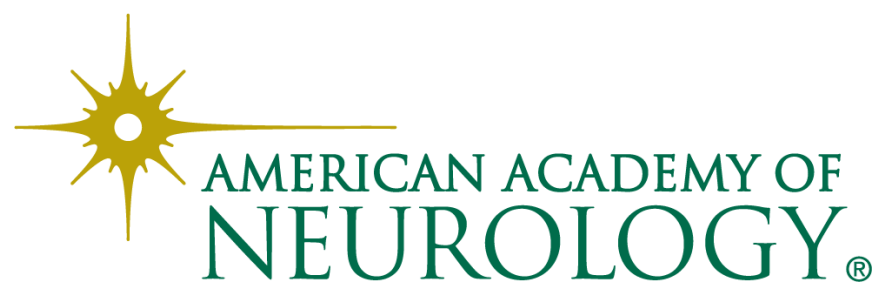

